\title{
Tri-trophic relationship among Sugarcane White Leaf Disease Phytoplasma (WLDP), Deltocephalus menoni (Homoptera: Cicadellidae) and sugarcane plant in secondary transmission of the disease
}

\author{
K. M. G. Chanchala ${ }^{1 *}$, V. K. A. S. M. Wanasinghe ${ }^{1}$, B. R. Kulasekara ${ }^{1}$, K. S. Hemachandra ${ }^{2}$, \\ L. Nugaliyadde ${ }^{3}$ and W. R. G. Witharama ${ }^{1}$
}

Received: $20^{\text {th }}$ October 2020 / Accepted: $26^{\text {th }}$ July 2021

\begin{abstract}
Purpose: Sugarcane White Leaf Disease (WLD) is one of the most devastative diseases in cane-sugar industry in Sri Lanka and the causative agent is a distinct phytoplasma (WLDP) strain within the 16SrXI. White Leaf Disease spreads through infected seed cane and insect vector; Deltocephalus menoni (Hemiptera: Cicadellidae). This paper presents the tri-trophic relationship of the plant, vector and pathogen in disease transmission.
\end{abstract}

Research Method: Four-month-old sugarcane plants of the variety SL 96128 and laboratory-reared populations of D. menoni were used for this study. Performance of D. menoni on healthy plants and WLD plants was examined in relation to the aggregation, amount of feeding, fecundity, number of nymphs emerged, nymphal period, survival of nymph and adult's longevity. The plant architecture, leaf histological and physiological aspects were also studied.

Findings: Except for nymphal period, all behavioural characteristics were significantly-high in WLDinfected plants in 10,14, 30, 8, 12 and 17 percent, respectively. The nymphal period of D. menoni was significantly-reduced by 12.78 percent. Number of shoots (41.83 percent) and leaves (18.96 percent) were high and distance between two leaves tends to be reduced by 32.85 percent in diseased-plants altering plant architecture into a profuse and bushy nature. Sucking distance, thicknesses of lower epidermis and phloem fibre layer in leaves were significantly reduced in infected plants. Leaf $N, P, K$ and moisture content increased (24.89, 34.78, 28.64 and 3.85percent) while leaf wax content was reduced by 4.93 percent.

Originality/value: Disease infected plants are augmenting its vector; D. menoni by attracting, enhancing survival and population build-up which promotes the transmission of WLD phytoplasma itself. There by regular inspection and rogueing out of WLD infected clumps make a great impact on secondary transmission of WLD by D. menoni.

Keywords: Behavioural characteristics, Biochemical, Leaf histology, Plant architecture, Sugarcane White Leaf Disease, vector

\section{INTRODUCTION}

White Leaf Disease (WLD) caused by phytoplasma strain within the group 16SrXI-B transmitted by an insect vector; Deltocephalus menoni (Hemiptera: Cicadellidae) has become one of the most devastative diseases in sugarcane industry in Sri Lanka (Senevirathne, 2008). WLD significantly and adversely affects the cane components and juice quality. Purity and Pure Obtainable Cane Sugar (POCS) of cane juice dropped by about $5 \%$ and $2 \%$ respectively, due to WLD, while fibre content in cane increased by about $2.5 \%$. The volume of juice extracted from healthy cane is about 350 $\mathrm{ml} / \mathrm{kg}$ of cane whereas for diseased cane, it is

\footnotetext{
1 Sugarcane Research Institute, Uda Walawe, Sri Lanka.

2 Faculty of Agriculture, University of Peradeniya, Sri Lanka.

3 Sri Lanka Organization of Agriculture Professionals, Department of Agriculture, Peradeniya.

*chanchala@sugarres.lk
}

https://orcid.org/0000-0002-8433-9372 
about $245 \mathrm{ml} / \mathrm{kg}$ (Chandrasena et al., 2003).

The disease spreads in sugarcane plantations, primarily, through infected seed-cane (Jayarathne, 1996) and secondarily, by an insect vector, Deltocephalus menoni (Hemiptera: Cicadellidae, Subfamily: Deltocephalinae) (Senevirathne, 2008). D. menoni has been the only identified vector that transmits WLD in Sri Lanka. True seeds do not carry phytoplasma (Lee et al., 2000) and this pathogen does not transmit mechanically through farm equipment by inoculation of sap (Lee et al., 2000) and is not air-borne (Senevirathne, 2006). Therefore, management of WLD vector has been identified as a strategic and integrated approach to prevent rapid spread of this disease in sugarcane plantations.

D. menoni lays eggs individually, in the soil or on the leaf sheaths, which are at the base of the plants. Sex ratio of D. menoni found to be significantly different from 1:1 (female: male) with high female percentage (Senevirathne, 2008). Fifty-eight percent of adult insects in the natural vector population are found to be viruliferous and capable of transmitting WLD after acquisition of the inoculum (Chanchala et al., 2019). Both adult and nymphal stages of the insect are capable of transmitting the disease (Chanchala et al., 2019) and the vector population positively correlates with the disease appearance of the crop (Chanchala et al., 2014).

Planting sugarcane in both "Yala" and "Maha" seasons provides year- round continued food source to the insect vector, enabling it to increase its population and consequently leads to a higher incidence of the disease.

When it comes to the interplays between herbivorous insects, plants and microbes, the relationship among each of them should be examined in a much broader ecological context (Pieterse and Dicke, 2007). With the immobile nature of plants and the strong pectin and cellulose barrier surrounding cells have constrained the most plant becoming susceptible to pathogen transmission (Gutierrez, 2013). Transmission of pathogens, particularly of phytoplasma, from host to host is a crucial step in the disease cycle. Therefore, pathogen species use vectors (mainly insects) for existence, transfer and entry from one host to another. When microbes are developing within plant hosts, they strive for the same resources as herbivorous insects; however, plant to plant transmission of microbes is mediated by vectoring herbivorous insects.

A growing body of evidence is showing that plant pathogens especially viruses and phytoplasma are capable of influencing vector physiology and behaviour to increase their chances of transmission, either directly or through modification of the host plant (Gutierrez, 2013).

Differences in population levels of $D$. menoni have been recorded in the fields with the same sugarcane variety with different levels of WLD infection (Senevirathne, 2008). Changes of sugarcane plants in plant morphology, physiology, histology and plant compounds along with the infection of WLD have been observed. These lead to a hypothesis that WLD-infected plant could be favourable for augmenting its vector. This study examines the tri-trophic relationship between WLD, WLD phytoplasma and its vector: D. menoni in secondary transmission of the disease.

\section{MATERIALS AND METHODS}

The study was conducted at the Sugarcane Research Institute (SRI), Uda Walawe, Sri Lanka during 2017-2018 with four-month-old healthy and WLD-infected sugarcane plants of the variety SL 96128 and laboratory-reared populations of $D$. menoni. Required cultures of D. menoni, WLD-infected plants and healthy plants were maintained using the following procedures.

Maintenance of insect cultures: The adult insects of $D$. menoni were collected using sweep nets and pooters from young sugarcane plants in the research farm, SRI, Uda Walawe. These insects were reared in insect-rearing cages following the protocol developed by Senevirathne (2008).

Raising WLD-infected plants: The WLDinfected sugarcane plants of the variety SL 96 128 were selected using external symptoms 
(Senevirathne, 2008) and seed setts (stem cuttings) for raising WLD-infected plants were obtained from those plants. The setts were planted in plastic pots of $20 \mathrm{~cm}$ radius filled with sterilized soil. Plants generated in this manner were kept in an insect proof house and maintained under recommended agronomic practices (SRI, 2004).

Raising healthy plants: Sugarcane plants produced through meristem culture using the $e x$ plants obtained from mother plant nursery of the variety SL 96128 were used in the experiment. These plants were also kept in an insect proof house and maintained under recommended agronomic practices (SRI, 2004).

\section{a. Behavioural characteristics of WLD vector in healthy and WLD-infected plants}

Aggregation: Four-month old two sugarcane potted-plants representing one healthy plant and WLD-infected plant were placed randomly but equidistantly apart in a circle with the radius of $15 \mathrm{~cm}$ inside the insect-proof laboratory cage. The arrangement was replicated nine times. Two-day old fifty adults of $D$. menoni were released from the centre and a choice test was conducted. The number of insects settled on each plant was recorded daily on $7.00 \mathrm{am}$ for ten days. Percentage of leafhoppers settled at each time on tested plants was calculated.

Amount of feeding: Feeding of D. menoni was recorded by honey-dew production on each test variety/accession, measured using Parafilm Sachet Technique and Erythrosine dye test (Heinrichs et al., 1985).

Fecundity: Four-month-old healthy and WLD infested plants were thoroughly cleaned and soil surface of each pot was covered with polythene as underpinnings to pave sterilized soil for oviposition. Five newly-emerged one day old adult vectors ( 3 females and 2 males) were introduced to each plant enclosed in an insect proof cage and left for five days for oviposition. Then, substrates in each pot were observed using a light microscope (Kyowa Tokyo, 10x3) and the number of eggs in soil were counted.

Number of nymphs emerged: The eggs collected from healthy and WLD-infected plants were separately counted and left on Petri dishes for two weeks until emergence of nymphs. Percentage of emerged nymphs was calculated.

Nymphal period and percentage of nymphs transformed into adults: Twenty-five neonatal nymphs were introduced to each healthy and WLD-infected plants and the setup was replicated nine times. The nymphs were allowed to develop without interferences until they reach the final ecdysis. Nymphal period i.e. the number of days taken by them to reach adulthood was recorded on each variety/ accession. The number of nymphs reached adult stage was also recorded and survival percentages were calculated.

Longevity of adults: Just after final ecdysis, twenty-five adults were introduced to each healthy and WLD-infested plants at fourmonth-old and this arrangement was replicated nine times. The number of days those adults survived on each variety/succession was recorded to calculate longevity of adults.

\section{b. Leaf histological aspects}

Third leaves of the healthy and WLD-infested sugarcane plants were collected and tissue samples excised from either side of the midrib, at a point midway along the length of the blade. Free hand sections were taken and thin cut sections were observed under microscope at higher magnification (Olympus, model CX31, $10 \mathrm{x}$ ). Photographs of the cross section were taken and the gross cross anatomy of the leaf blade was observed. Following measurements were taken viz., thickness of the abaxial epidermis, and distance from abaxial epidermis to vascular bundle (Sucking distance) and thickness of the phloem fibre layer.

\section{c. Leaf biochemical}

Three replicates were conducted for each test using third leaf of the four-month-old plants.

Leaf Nitrogen, Potassium and phosphorous: Leaf samples were digested using wet digestion method. Leaf N, P and K were analysed using UV spectrophotometer and Atomic absorption spectrophotometer respectively. 
Moisture content: Third leaves of the healthy and WLD-infested sugarcane plants were collected and $15 \mathrm{~cm}$ long tissue samples excised from the point midway along the length of the blade. 10 $\mathrm{g}\left(\mathrm{W}_{1}\right)$ of fresh leaves were taken and kept in a drying oven at $65{ }^{\circ} \mathrm{C}$, for 72 hours. After drying, the weight of leaves was taken and placed back in oven at the same temperature for another six hours. Leaves were taken out from the oven and kept in a desiccator for 10 minutes and weighed $\left(\mathrm{W}_{2}\right)$. When the weight becomes constant, the moisture percentages were calculated, according to the following formula: $\left(\mathrm{W}_{1}-\mathrm{W}_{2}\right) /$ $\mathrm{W}_{1} \times 100$.

Level of Epicuticle wax: At the age of four months, 10 numbers of third leaves of the plants were detached and the middle portions of leaves were taken for wax extraction. The area $\left(\mathrm{cm}^{2}\right)$ of the selected leaf portions were measured using square millimetre grid. The leaf portions were immersed in $99.9 \%$ analytical grade chloroform for about 10 seconds and the extracts were evaporated to separate wax. The amount of wax was weighed and calculated for unit area $\left(\mathrm{cm}^{2}\right)$ (Nugaliyadde, 1994).

\section{d. Plant architecture}

Number of shoots per clump and number of leaves per stalk were counted on four-monthold sugarcane plants. Distance between two leaves was calculated by averaging distances between the top five leaves.

\section{Statistical analysis}

Transformed data were tested for the normality using Proc univariate test and analysis of variance was conducted to test the significance of insect behavioural characteristics, leaf histology, leaf compositions and plant architecture, between healthy and WLD-infected plants. Means were separated by using Duncan's Multiple Range Test (DMRT) at 0.05 probability level.

\section{RESULTS AND DISCUSSION}

\section{a. Behavioural characteristics of WLD vector in healthy and WLD-infected plants}

Behavioural characteristics of WLD vector, D. menoniwere significantly different between WLD infected and healthy plants (Table 01).

\section{TABLE 01: Behavioural characteristics of WLD vector on four-month-old healthy and}

WLD-infected plants.

\begin{tabular}{lllc}
\hline \multicolumn{1}{c}{$\begin{array}{c}\text { Behavioral characteristics of } \\
\text { D. menoni }\end{array}$} & Healthy plant & WLD-infected plant & Difference \\
\hline Aggregation (no. of insects) & $17.17 \pm 1.16^{\mathrm{b}}$ & $19.07 \pm 0.05^{\mathrm{a}}$ & 10.00 \\
Amount of feeding $\left(\mathrm{mm}^{2}\right)$ & $31.59 \pm 0.80^{\mathrm{b}}$ & $36.73 \pm 0.37^{\mathrm{a}}$ & 14.00 \\
Number of salivary flanges & $01.45 \pm 0.02^{\mathrm{b}}$ & $01.59 \pm 0.20^{\mathrm{a}}$ & 08.80 \\
Oviposition (no. of eggs) & $17.90 \pm 0.31^{\mathrm{b}}$ & $25.68 \pm 0.25^{\mathrm{a}}$ & 30.00 \\
Number of emerged nymphs & $13.20 \pm 0.33^{\mathrm{b}}$ & $14.34 \pm 0.31^{\mathrm{a}}$ & 08.00 \\
Nymphal period (d) & $14.31 \pm 0.33^{\mathrm{a}}$ & $12.48 \pm 0.29^{\mathrm{b}}$ & 12.78 \\
Survival of nymphs (\%) & $61.71 \pm 0.60^{\mathrm{b}}$ & $70.13 \pm 0.60^{\mathrm{a}}$ & 12.00 \\
Adult longevity (d) & $38.00 \pm 0.57^{\mathrm{b}}$ & $45.78 \pm 0.37^{\mathrm{a}}$ & 17.00 \\
\hline
\end{tabular}

Note: In a row, means $( \pm S E)$ followed by common letters are not significantly different in 5\% probability level. 
Ten percent higher aggregation level of the D. menoni adults on WLD infected plants, indicated higher attraction of $D$. menoni to the infected plant. Amount of feeding on WLD infected plant was 14 percent higher compared to a healthy plant showing higher preference of D. menoni to infected plants for feeding.

Fecundity of the vectors on infected plant was 30 percent higher than the healthy plants. The egg hatching was also higher on infected plants than on healthy plants. Nymphal period of $D$. menoni was significantly low on WLD-infected plants by 12.78 percent, showing accelerated growth. Five Nymphal instars of D. menoni on WLD-infected plant had the development period $1,2,2,3$, and 3 days respectively. Third and fifth instar periods on healthy plants were three and five days, subsequently D. menoni requires extra three days to complete nymphal period. Survival percentages of the nymphs and adults were high on infected plants. Adult survival on infected plants was 17 percent higher than on healthy plants (Table 01).

These results revealed that the performance of D. manoni was significantly higher on WLD infected plants than on healthy plants. This may lead to the rapid population build-up on WLD infected plants.

The finding of the present study is in agreement with some of the previous works. In numerous vectors, the pathogen effects on fitness of the vector such as longevity, growth rate and reproduction (Kuno and Chang, 2005), as well as on feeding behaviours, facilitating viral transmission (Platt et al., 1997).

Laura et al (2012) confirmed that not- virulified aphid, Rhopalosiphum padi, prefers to settle and feed on wheat infected with Barley Yellow Dwarf Virus (BYDV). Potato plants, infected by Leafroll Virus (PLRV), indirectly induce changes in the host selection behavior of their respective principal aphid vectors, Rhopalosiphum padi and Myzus persicae (Eigenbrode et al., 2002; Werner et al., 2009).

Miller and Coon (1964) have observed short nymphal period of Macrosiphum granarium: vector of Yellow Dwarf Virus in barley. Srinivasan and Chelliah (1980) reported similar results in leaf hopper vector Hishimonous phycitis on eggplants infected by little leaf disease. Jayaraj and Seshadri (1967) and Miller and Coon (1964) reported the reduced mortality in nymphs which fed on infected plants. Srinivasan and Chelliah (1980) revealed the vector preference of diseased plants in Emilia sanchifolia, sugarbeet, and Seasumum.

\section{b. Leaf histological aspects}

Thicknesses of abaxial epidermis, sucking distance (distance from abaxial epidermis to vascular bundle), and phloem fibre layer in leaves were significantly reduced in infected plants in 22.1, 24.15 and 31.57 percent, respectively (Table 2).

TABLE 2: Leaf histological aspects of four-month-old healthy and WLD-infected plants.

\begin{tabular}{lccc}
\hline \multicolumn{1}{c}{ Leaf histological aspects } & Healthy plant & WLD-infected plant & Difference \\
\hline Thickness of the Epidermis $(\mu \mathrm{m})$ & $21.61 \pm 0.16^{\mathrm{a}}$ & $16.83 \pm 0.07^{\mathrm{b}}$ & 22.12 \\
Sucking distance $(\mu \mathrm{m})$ & $247.2 \pm 0.14^{\mathrm{a}}$ & $187.5 \pm 0.04^{\mathrm{b}}$ & 24.15 \\
Phloem fiber layer $(\mu \mathrm{m})$ & $48.96 \pm 0.11^{\mathrm{a}}$ & $33.44 \pm 0.05^{\mathrm{b}}$ & 31.57 \\
\hline
\end{tabular}

Note: In a row, means $( \pm S E)$ followed by common letters are not significantly different in $5 \%$ probability level. 
Since, D. menoni is a phloem feeding leaf hopper, reduced thicknesses of abaxial epidermis and sucking distance are advantages for the vector to get an easy access to the phloem for feeding. Reduced thickness of the phloem fibre layer causes to reduce resistance to penetrate the leaf and provide easy access to the phloem tube comparatively to the healthy leaves. It has been confirmed that, sucking distance and thickness of phloem fibre layer directly and negatively correlate with the feeding amount of the WLD vector (SRI, 2017). It was also observed that infected leaves become soft and glabrous providing more access to the vectors. These alterations which are taken place in leaves of WLD-infected plants enhance the amount of feeding of the vector on WLD-infected plants causing increased preference of feeding on infected leaves comparatively to the healthy leaves.

\section{c. Leaf Bio-chemicals}

Leaf $\mathrm{N}, \mathrm{P}, \mathrm{K}$ and moisture percentage were significantly high $(p<0.05)$ in leaves of WLDinfected plants (Table 3) which may provide a higher level of nutrition and moisture for performance of the WLD vector.

Level of epicuticle wax on leaves of WLDinfected plants was significantly less than that of in healthy plants. Chanchala et al. (2019) confirmed that level of leaf lamina epicuticle wax positively correlates with the feeding amount of $D$. menoni which may confirm the fact that, significantly lower amount of wax on leaves of WLD-infected plants facilitates higher feeding of the vector and there by enhances growth and development of the insect.

Jaiswall and Bhatia (1971) reported that due to impaired photosynthesis, total $\mathrm{N}$ content increases in sugarcane WLD infected leaves and degradation of protein into free amino acids causes for high amino acid content in phloem sap. Stockhoff (1993) confirmed that, female vectors have higher protein requirements associated with egg production and Dixon (1970) recorded that, when amino acid content of the phloem is high, fecundity increases in aphids, which may demonstrate the higher fecundity of the WLD vectors which feed on infected plants.

Accordingly, fluctuations of the biochemical components in WLD infected and healthy sugarcane plants provide confirmation for the higher preference of WLD vector to infected plants. This phenomenon highly contributes to the multiplication and survival of the vector.

\section{d. Plant architecture}

Number of shoots (41.83 percent) and leaves (18.96 percent) per clump were high and distance between leaves tends to be reduced by 32.79 percent in diseased-plants altering plant architecture into a profuse and bushy nature.

TABLE 3: Leaf compositions of four-month-old healthy and WLD-infected plants.

\begin{tabular}{lccc}
\hline \multicolumn{1}{c}{ Leaf Compositions } & Healthy plant & WLD-infected plant & Difference \\
\hline Leaf N & $1.84 \pm 0.01^{\mathrm{b}}$ & $2.45 \pm 0.01^{\mathrm{a}}$ & 24.89 \\
Leaf P & $0.15 \pm 0.01^{\mathrm{b}}$ & $0.23 \pm 0.01^{\mathrm{a}}$ & 34.78 \\
Leaf K & $1.42 \pm 0.01^{\mathrm{b}}$ & $1.99 \pm 0.01^{\mathrm{a}}$ & 28.64 \\
Moisture per centage & $7.12 \pm 0.01^{\mathrm{b}}$ & $7.49 \pm 0.01^{\mathrm{a}}$ & 04.93 \\
Level of epicuticle wax $(\mathrm{mg})$ & $2.3 \pm 0.001^{\mathrm{a}}$ & $2.1 \pm 0.001^{\mathrm{b}}$ & 05.00 \\
\hline
\end{tabular}

Note: In a row, means $( \pm S E)$ followed by common letters are not significantly different in $5 \%$ probability level. 
TABLE 4: Plant architecture of four-month-old healthy and WLD-infected plants.

\begin{tabular}{lccc}
\hline \multicolumn{1}{c}{ Plant architecture } & Healthy plant & WLD-infected plant & Difference \\
\hline Number of shoots/clump & $10.12 \pm 0.08^{\mathrm{b}}$ & $17.4 \pm 0.01^{\mathrm{a}}$ & 41.83 \\
Number of leaves & $09.40 \pm 0.05^{\mathrm{b}}$ & $11.6 \pm 0.02^{\mathrm{a}}$ & 18.96 \\
Distance between leaves & $04.91 \pm 0.01^{\mathrm{a}}$ & $03.3 \pm 0.05^{\mathrm{b}}$ & 32.79 \\
\hline
\end{tabular}

Note: In a raw, means ( \pm SE) followed by common letters are not significantly different in 5\% probability level.

It was found that feeding amount and nymphal survival of $D$. menoni have significantly negatively correlated with distance between leaves which may confirm the fact that altered profuse and bushy appearance of infected plants facilitate insect feeding, growth and development. The profuse and bushy nature induced by WLD phytoplasma provides optimum micro-environment for the survival and multiplication of D. menoni.

Several authors (Mauck et al., 2012; Mauck et al., 2016) have confirmed that, phytoplasma and virus infections can fundamentally alter the way that host plants interact with other organisms. In particular, many pathogens change host plant phenotypes in ways that influence interactions with vectors with significant implications for transmission.

Secondary metabolites produced by plants are a major factor attracting insects and also specific plant properties such as size, shape, colour, odour and taste, provide visual cues to herbivorous insects attracting more insects eventually manipulating their vectors (Ajayi and Dewar 1983; Mauck, De Moraes et al., 2010)

\section{REFERENCES}

Ajayi, O. and Dewar, A. M. (1983). The effect of Barley yellow dwarf virus on field populations of the cereal aphids, Sitobion avenae and Metopolophium dirhodum. Annals of Applied Biology. 103: $1-11$.

Chanchala, K.M.G., Wanasinghe, V.K.A.S.M., Hemachandra, K.S., Nugaliyadde, L. and Witharama, W.R.G. (2020). Effect of the Epicuticular Wax Level of Leaf Lamina on the Behaviour of Leaf Hopper Deltocephalus menoni (Hemiptera: Cicadellidae); A Vector of Sugarcane White Leaf Disease. Tropical Agricultural Research, 31(1): 73-85. DOI: http://doi.org/10.4038/tar.
$\mathrm{Ng}$ and Falk (2006) discussed that, noncirculative pathogens are favoured by vectors making brief probes and then rapidly dispersing from infected plants to healthy plants as vector preference is temporary changed after pathogen acquisition. Since D. menoni recorded as a non-persistence vector, further studies on transmission efficacy and mechanism of transmission from infected to healthy plant is important.

\section{CONCLUSIONS}

D. menoni population feed on WLD-infected plants increases within a comparatively-shorter period of time than its population feed on healthy plants. Alterations occurred in plant structure and composition of leaf tissues due to WLD infection which facilitates increase of vector population through rapid population build-up and easy stylet penetration during feeding. White Leaf Disease infected plants are augmenting its vector; $D$. menoni by attracting, enhancing survival and population build-up, promoting the transmission of WLD phytoplasma itself, there by regular inspection make a great impact on secondary transmission of WLD by $D$. menoni. and rogueing out of WLD infected clumps 
Chanchala K.M.G., Dayasena Y.A.P.K., Wanasinghe, V.K.A.S.M., Hemachandra, K.S., Nugaliyadde, L., and Witharama, W.R.G. (2019). Viruliferous nature of the Sugarcane White Leaf Disease Vector Deltocephalus menoni (Hemiptera: Cicadellidae). Proceedings of the Seventh Symposium on Plantation Crop Research- "Towards Achieving Sustainable Development Goals in the Plantation Sector". Dr. VHL Rodrigo, Dr. BW Wijesuriya, Dr. DG Edirisinghe, Dr. NMC Nayanakantha (Eds). Rubber Research Institute of Sri Lanka, Dartonfield, Agalawatta, 12200, Sri Lanka. 153-162

Chanchala, K.M.G., Wanasinghe, V.K.A.S.M., Ariyawansa, B.D.S.K. and Hemachandra, K.S. (2014). Relationship between the incidences of Sugarcane White Leaf Disease and the population dynamics of its vector, Deltocephalus menoni. In A P Keerthipala (ed) Proceedings of the 5th Symposium on plantation Crop Research - "Towards a Green Plantation Economy" Sugarcane Research Institute, Uda Walawe, 70190, Sri Lanka. 143-149.

Dixon, A.F.G. (1970). Quality and availability of food for a sycamore aphid population. In Animal Populations in Relation to Their Food Resources, Ed. A Watson, pp.271-87. Oxford: Blackwell Science.

Eigenbrode, S. D., Ding, H., Shiel, P. and Berger, P. H. (2002). Volatiles from potato plants infected with potato leafroll virus attract and arrest the virus vector, Myzus persicae (Homoptera: Aphididae). Proceedings of the Royal Society B: Biological Sciences. 269, 455-460.

Gutierrez, S., Michalakis, Y., van Munster, M. and Blanc., S. (2013). Plant feeding by insect vectors can affect life cycle, population genetics and evolution of plant viruses Functional Ecology 27(3):610-622 DOI: 10.2307/23481023

Heinrichs, E. A.; Medrano and F. G. Rapusas, H. R. (1985). Genetic variation for insect resistant in rice. Los Banos, Laguna, IRRI, 118-28

Jaiswal, S.P. and Bhatia, I.S. (1971). The metabolic changes in sugarcane associated with grassy shoot disease. Sugar Azawar. 66:15-16.

Jayaraj, S. and Seshadri, A.R. (1967). Preference of the leafhopper, Empoasca kerri Pruthi (Homoptera, Jassidae) to pigen pea, cajanus cajan (L.) Millsp. Plants infected with sterility mosaic virus; Currant Science. 36: 353- 355.

Kuno, G. and Chang, G.J. (2005). Biological transmission of arboviruses: reexamination of and new insights into components, mechanisms, and unique traits as well as their evolutionary trends. Clinical Microbiology Reviews. 18: 608-637.

Laura L. Ingwell, Sanford D. Eigenbrode and Nilsa A. Bosque-Pe'rez. (2012). Plant viruses alter insect behavior to enhance their spread. Scientific reports. 2, 578; DOI:10.1038/srep00578

Lee, I. M., Davis, R.E. and Gundersan-Rindal, D.E. (2000). Phytoplasma., Pathogenic Molecutes. Annual Revive of Mocrobiology. 54: 221-255.

Mauck, K, Bosque-Pe' rez, N.A., Eigenbrode, S.D., De Moraes, C.M. and Mescher, M.C. (2012), Transmission mechanisms shape pathogen effects on host-vector interactions: evidence from plant viruses. Functional Ecology. 26:1162-1175. 
Mauck, K, De Moraes C.M. and Mescher M.C. (2016). Effects of pathogens on sensory-mediated interactions between plants and insect vectors. Current Opinion in Plant Biology. 32:53-61.

Mauck, K. E., De Moraes, C. M. and Mescher, M. C. (2010). Deceptive chemical signalsinduced by a plant virus attract insect vectors to inferior hosts. Proceedings of the National Academy of Sciences. U. S. A. 107, 3600-3605.

Miller, J. W. and B. F. Coon. (1964). The effect of barleyyellow dwarf virus on the biology of its vector the English grain aphid, Macrosiphum granarium. Jurnal of Economic Entomology. 57(6): 970-974.

Ng, J.C. and Falk B.W. (2006). Virus-vector interactions mediating nonpersistent and semipersistent transmission of plant viruses. Annual Review of Phytopathology. 44:183-212.

Nugaliyadde, L. (1994). Factors associated with the resistance of Rice (Oriza sativa L.) to Nilapawata Lugens (Stål). PhD Thesis, University of Newcastle upon Tyne, United Kingdom

Pieterse, C. and Dicke, M. (2007). Plant interactions with microbes and insects: from molecular mechanisms to ecology. Trends in Plant Science 12(12): 564-569.

Seneviratne, J.A.U.T. (2008). An investigation of the secondary transmission of sugarcane white leaf disease in Sri Lanka, PhD Thesis, University of Peradeniya, Sri Lanka.

Seneviratne, J.A.U.T., Bandara. J.M.R.S., Ahangama, D. and Huaping, L. (2006). Mode of transmission of Sugarcane (Saccharum officinarum L.)White Leaf phytoplasma in Sri Lanka. Tropical Agriculture Research. 18: 153-162.

SRI. (2004). Methods of Sugarcane cultivation. Bulletin No. 01 (Edited). Publication of Sugarcane Research Institute.

SRI. (2017). White leaf Disease of Sugarcane. Bulletin No. 04 (Edited).

SRI. (2017). Progress report of Division of Crop Protection, Sugarcane Research Institute.

Srinivasan, K. and Chelliah, S. (1980). The mechanism of preference of the leaf hopper Vector, Hishimonous phycitis (Distant) for egg plants infected with Little Leaf Disease. Proceedings of Indian national science academy. 6: 786-796

Stockhoff B. (1993). Ontogenic change in dietary selection for protein and lipiby gypsy moth larvae. Journal of Insect Physiology. 39:677-86

Werner, B. J., Mowry, T. M., Bosque-Pe'rez, N. A., Ding, H. and Eigenbrode, S. (2009). Changes in green peach aphid responses to potato leafroll virus-induced volatiles emitted during disease progression. Environmental Entomology. 38, 1429-1438. 